\title{
E-Government Portals Maturity Models: A Best Practices' Coverage Perspective
}

\author{
Abdoullah Fath-Allah ${ }^{1}$, Laila Cheikhi ${ }^{1}$, Rafa E. Al-Qutaish ${ }^{2}$, Ali Idri ${ }^{1}$ \\ ${ }^{1}$ Software Project Management Research Team, ENSIAS - Mohammed V University, Rabat, Morocco. \\ 2 Dept. of Software Engineering \& IT, École de Technologie Supérieure, University of Québec, Montréal, \\ Canada. \\ * Corresponding author. Tel.: +212661496680; email: hazgour.abdoullah@gmail.com \\ Manuscript submitted February 10, 2015; accepted June 10, 2015. \\ doi: 10.17706/jsw.10.7.805-824
}

\begin{abstract}
E-government is a field where oriented practice is considered crucial for its prosperity. Therefore, best practices are considered among the success factors of e-government portals. To this end, e-government maturity models can be used to provide guidance and guidelines to identify those best practices. After an extensive literature review, we have collected both; the e-government portals' best practices and organized them according to their purposes in an e-Government Portals' Best Practice Model (eGPBPM), and the set of 25 maturity models best practices in two separated previous published studies. The eGPBPM is composed of four best practice categories including: back-end, Web design, Web content and external. Moreover, each maturity model has several stages of maturity and each stage include a set of best practices used to rank the maturity of e-government portals. The goal of this paper is to identify the extent to which e-government maturity models are covering the best practices of the eGPBPM. To achieve this goal, a mapping between the maturity models' best practices for each maturity stage and the best practices of the eGPBPM has been performed. Our findings show that although this set of maturity models are used in practice, they include only some of the e-government portals' best practices and none of them have a full coverage of those best practices.
\end{abstract}

Key words: E-Government, maturity model, best practices, e-government portal.

\section{Introduction}

E-government can be defined as the use of internet to deliver online services to the citizens. E-government portals can be used to deliver those services. The success of an e-government portal depends on its implementation, design and the services offered to the users [1]. However, there is no textbook or theory for e-government [2], since it is considered as an emerging field of interdisciplinary research in which practical recommendations are important features [3]. This is why, practical recommendations, case studies and best practices are considered important in building e-government portals. To this end, e-government maturity models can serve as a guide for agencies to enhance their portals' quality. Furthermore, they can also be used to determine the missing best practices at any given stage of maturity and provide recommendations to move to higher stages.

To this end, we have conducted an extensive literature review to identify the e-government portals' best practices in [1]. However, after collecting those best practices it has been noticed that they are not logically grouped. Besides that, some best practices was raised by some authors with the same meaning, but with 
different wordings such as customer centricity that can be named as user focus or customer-centric [4], user-centric [5] or customer intention [6]. For this purpose, the best practices' wordings have been unified and grouped in a logical way, which is composed of four best practice categories (back-end, Web design, Web content and external). This can help practitioners and researchers to build e-government portals' easily.

An e-government portal's maturity model is a set of evolutionary stages that determines the maturity of the e-government portals. The maturity models offer a way to rank e-government portals and guide agencies to enhance their portals' quality [7]. In fact, many e-government maturity models exist in the literature and for a practitioner choosing one among the others should be done based on a strong basis, such as, the practitioner purposes and the maturity model best practices or features that will satisfy the stakeholders. For example, Lee and Kwak maturity model focuses on open government and e-participation, however other maturity models such as Layne and Lee [8] and United Nations [9] focus on e-government best practices from a global perspective. To this end, we have conducted an extensive literature review to identify the e-government portals' best practices of 25 maturity models in [7]. The purpose of this paper is to identify to which extent this set of 25 e-government maturity models are covering the best practices presented in the e-Government Portals' Best Practices Model (eGPBPM).

This paper is structured as follow: Section 2 and Section 3 provide respectively an overview on the implemented best practices in the e-government portals maturity models and the best practices of the eGPBPM, whereas, Section 4 provides the mapping conducted between the e-government portals' best practices (as in the eGPBPM) and the 25 e-government maturity models' best practices. Section 5 synthetize and discuss the result of the mapping. Finally, Section 6 concludes the paper and gives directions for future work.

\section{E-Government Portal Maturity Models}

E-government best practices from 25 maturity models were collected during an extensive literature review in a previous study [7]. The 25 maturity models are: Layne and Lee [8], Andersen and Henriksen [10], United Nations [9], Alhomod et al. [11], Hiller and Belanger [12], Almazan and Gil-Garcia [13], Cisco [14], Karokola et Yngström [15], West [16], Moon [17], World Bank [18], Deloitte and Touche [19], Howard [20], Shahkooh et al. [21], Lee and Kwak [22], Siau and Long [23], Wescott [24], Chandler and Emanuel [25], Kim and Grant [26], Chen [27], Windley [28], Reddick [29], Accenture [30], UK National Audit Office [31] and Netchaeva [32].

These maturity models have different stages varying from 2 to 6 . Table I through IV in the Appendix summarize the best practices of the maturity models with 2 and 3 stages, 4 stages, 5 stages and 6 stages respectively.

From those tables, it can be concluded that the focus of the maturity models differs from a maturity model to another. Besides that, they focus on different aspects and perspectives of e-government (such as G2C, G2G and Open government). Furthermore, while some maturity models are introducing new best practices, it seems that others are just ignoring them, such as: measuring performance and analytics for decision making introduced only by the Lee and Kwak model and ignored by all the others [7]. This can be explained by the fact that all the maturity models have been built without any input of the existing models or best practices, with the exception of Almazan and Gil-Garcia, Shahkooh et al, Siau and Long, and Kim and Grant maturity models [7]. This may result in the absence of some best practices already raised by other authors. Besides that, it can be noticed that the most important stages of maturity can be summarized into 4 different stages as the following: presence, interaction, transaction and integration. 


\section{E-Government Portal Best Practice Model}

We have collected e-government portals' best practices from literature to build a best practice model in [1]. The model is composed of four best practice categories, each category contains subcategories. Fig. 1 summarizes the model, and Tables V to VIII in the Appendix provide details, advantages and examples for each best practice subcategory. The best practice categories are explained below.

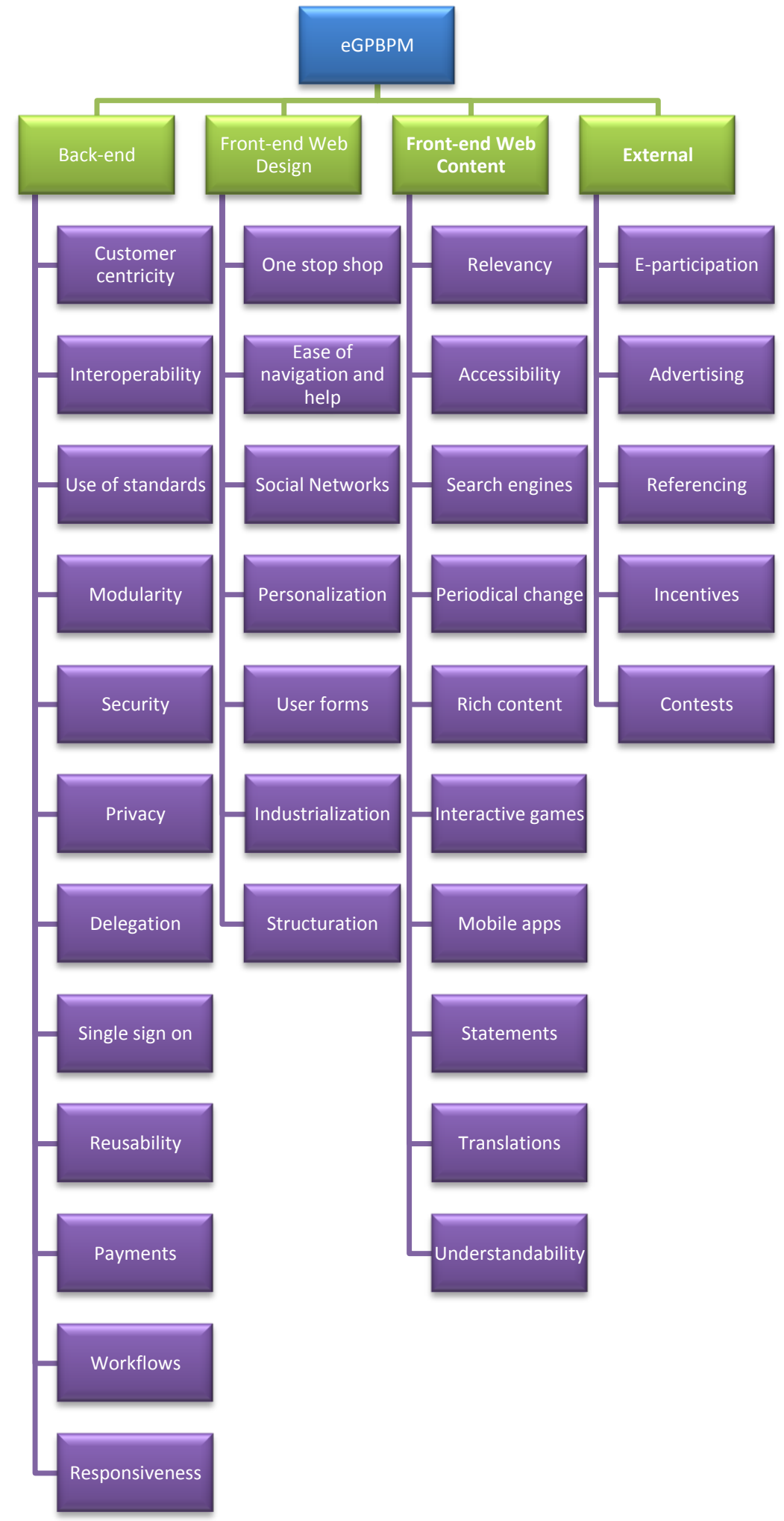

Fig. 1. Best practice model [1]. 


\subsection{Back end Category}

Back-end best practices can be defined as the best practices that run in background and usually the users do not see them (such as: system, data processing and business logic best practices). This includes: customer centricity, interoperability, use of standards, modularity, security, privacy, delegation, single sign on, reusability, payments, workflows and responsiveness (see Table V in the Appendix).

\subsection{Front-end Web Design Category}

Front-end - Web design best practices can be defined as the best practices that the user usually interacts with and sees, and are related to the interface or design of the portal. This includes: one stop shop, ease of navigation and help, social networks, personalization, user forms, industrialization and structuration (see Table VI in the Appendix).

\subsection{Front-end Web Content Category}

Front-end - Web content best practices can be defined as the best practices that the user usually interacts with and sees and are related to the information and content of the portal. This includes: relevancy, accessibility, search engines, periodical change, rich content, interactive games, mobile apps, statements, translations and understandability (see Table VII in the Appendix).

\subsection{External Category}

External best practices can be defined as the best practices that are loosely coupled with the technical aspects of the portal and are mostly related to the marketing of the portal and to the inclusion of the citizen in the e-government process. This includes: e-participation, advertising, referencing, incentives and contests (see Table VIII in the Appendix).

\section{Mapping between the Maturity Models and the Best Practice Model}

This section presents the mapping conducted between the maturity models' best practices and the best practice subcategories of the best practice model. The purpose is to identify to which extent the maturity models are covering the e-government portals' best practices.

Table 1. Mapping between Maturity Stages and Back-end Best Practice Subcategories

\begin{tabular}{|c|c|c|c|c|c|}
\hline $\begin{array}{l}\mathrm{BP} \\
\text { subcategories }\end{array}$ & Stage 1 & Stage 2 & Stage 3 & Stage 4 & $\begin{array}{l}\text { Stage } 5 \text { and } \\
\text { above }\end{array}$ \\
\hline $\begin{array}{l}\text { Customer } \\
\text { Centricity }\end{array}$ & NA & NA & [19], [30] & {$[10],[9],[13],[28]$} & {$[30]$} \\
\hline $\begin{array}{l}\text { Vertical } \\
\text { Interoperability }\end{array}$ & [10] & NA & {$[8],[14],[27],[30]$} & $\begin{array}{l}\text { [9], [11], [12], [33], [17], } \\
{[21],[22], \quad[23],[25],} \\
{[26],[28]}\end{array}$ & $\begin{array}{l}\text { [13], [19], [22], } \\
{[24],[31]}\end{array}$ \\
\hline $\begin{array}{l}\text { Horizontal } \\
\text { Interoperability }\end{array}$ & {$[10]$} & NA & [14], [30] & $\begin{array}{l}\text { [8], [9], [11], [12], [33], } \\
{[17],[21],[23],[25],[28]}\end{array}$ & $\begin{array}{l}\text { [13], [19], [22], } \\
{[24],[31]}\end{array}$ \\
\hline Use of standards & NA & NA & NA & NA & NA \\
\hline Modularity & NA & NA & NA & NA & NA \\
\hline Security & NA & [19], [30] & $\begin{array}{l}\text { [9], [14], [33], [18], [21], } \\
{[22]}\end{array}$ & [13], [24], [28], [31] & NA \\
\hline Privacy & NA & [19] & {$[33],[22],[25]$} & NA & {$[12]$} \\
\hline Delegation & NA & NA & NA & NA & NA \\
\hline Single Sign on & NA & NA & NA & NA & {$[22]$} \\
\hline Reusability & NA & NA & NA & NA & NA \\
\hline Payments & NA & $\begin{array}{l}{[14],[19],} \\
{[28],[29]}\end{array}$ & $\begin{array}{l}\text { [9], [11], [12], [33], [17], } \\
{[20],[21],[23],[19],} \\
{[26]}\end{array}$ & {$[13],[24],[28],[31],[32]$} & {$[24]$} \\
\hline Workflows & NA & [24] & NA & [28], [31] & NA \\
\hline Responsiveness & NA & NA & NA & NA & NA \\
\hline
\end{tabular}


The criteria used for the mapping are the best practice subcategories (as described in Tables V to VIII in the Appendix) and the stages of the maturity models. Since those stages include the best practices, in the mapping we identify for each stage of maturity, the maturity models that included the best practice subcategories. It is important to note that in this mapping, if a maturity model contains just a feature of the best practice subcategory then the whole subcategory is marked as existing.

\subsection{Mapping between the Maturity Models and Back-end Best Practices}

Table 1 summarizes the mapping conducted between the stages of each maturity model among the 25 models and the back-end best practice subcategories. The 'Stage' column represents the stages of the maturity models and the 'BP subcategories' column represents the back-end best practice subcategories described in Table $\mathrm{V}$ in the Appendix. If the best practice subcategory is not covered by the maturity model, it is marked as not available 'NA'.

It can be noticed from Table 1 that all the maturity models address only some of the back-end best practice subcategories. While none of them address all the back-end subcategories. Furthermore, there are some best practice subcategories that are not covered by any maturity models such as: use of standards, modularity, delegation, reusability and responsiveness.

\subsection{Mapping between the Maturity Models and Web Design Best Practices}

Table 2 shows the mapping between the maturity stages of each maturity model and the Web design best practice subcategories. The 'BP subcategories' column represents the Web design best practice subcategories described in Table VI in the Appendix.

Table 2. Mapping between Maturity Stages and Design Best Practice Subcategories

\begin{tabular}{|l|l|l|l|l|l|}
\hline \multicolumn{1}{|c|}{$\begin{array}{l}\text { Stage } \\
\text { subcategories }\end{array}$} & Stage 1 & Stage 2 & Stage 3 & Stage 4 & Stage 5 and above \\
\hline One stop shop & NA & {$[29]$} & {$[16],[19]$} & {$[8],[12],[21],[23]$} & $\begin{array}{l}{[13],[24],[31],} \\
{[32]}\end{array}$ \\
\hline $\begin{array}{l}\text { Ease of } \\
\text { navigation }\end{array}$ & NA & {$[28],[32]$} & NA & NA & {$[22],[24]$} \\
\hline Social Networks & NA & {$[22]$} & {$[22]$} & {$[9]$} & NA \\
\hline Personalization & {$[14]$} & {$[10]$} & {$[10],[13],[14],[23],[31]$} & $\begin{array}{l}{[13],[33],[16],[19],} \\
{[31]}\end{array}$ & {$[19]$} \\
\hline User forms & {$[14]$} & {$[8],[27],[28]$} & $\begin{array}{l}{[9],[11],[12],[33],[17],} \\
{[18],[21],[23],[20]}\end{array}$ & {$[28]$} & NA \\
\hline Industrialization & NA & NA & NA & NA & NA \\
\hline Structuration & NA & NA & NA & NA & NA \\
\hline
\end{tabular}

From the above, it can be deduced that all the maturity models address only some of the design best practice subcategories and no maturity model is covering all of them. Moreover, two best practice subcategories (including industrialization and structuration) are not covered by any maturity model. Furthermore, it can be noticed that some authors raise the same best practice in different stages; but it is more sophisticated in higher stages.

\subsection{Mapping between the Maturity Models and Web Content Best Practices}

Table 3 displays the mapping between the maturity stages of each maturity model and the content best practice subcategories. The 'BP subcategories' column represents the Web content best practice subcategories described in Table VII in the Appendix. 
Table 3. Mapping between Maturity Stages and External Best Practice Subcategories

\begin{tabular}{|l|l|l|l|l|l|}
\hline $\begin{array}{l}\text { BP } \\
\text { subcategories }\end{array}$ & Stage 1 & Stage 2 & Stage 3 & Stage 4 & Stage 5 and above \\
\hline Relevancy & NA & {$[22]$} & {$[10]$} & $\begin{array}{l}{[9],[28],} \\
{[30]}\end{array}$ & {$[19]$} \\
\hline Accessibility & NA & NA & {$[16]$} & NA & {$[22]$} \\
\hline Search engines & NA & $\begin{array}{l}{[33],[16],[23],} \\
{[26]}\end{array}$ & {$[13],[31]$} & NA & NA \\
\hline Periodical change & {$[12],[23]$} & {$[13],[22]$} & NA & NA & NA \\
\hline Rich content & {$[9],[16],[18]$} & {$[9]$} & {$[24]$} & NA & NA \\
\hline Interactive Games & NA & NA & NA & NA & NA \\
\hline Mobile Apps & NA & NA & NA & NA & NA \\
\hline Statements & {$[28]$} & {$[16],[22]$} & {$[16]$} & NA & NA \\
\hline Translation & NA & {$[9]$} & {$[16]$} & NA & NA \\
\hline Understandability & NA & NA & NA & NA & NA \\
\hline
\end{tabular}

From Table 3, it can be noticed that no maturity model is covering all the best practice subcategories. Furthermore, all the maturity models address only few content best practice subcategories. Besides that, there are some best practice subcategories that are not covered by any maturity models including: interactive games, mobile apps and understandability. Moreover, some authors address the same best practice in different stages with a difference in sophistication.

\subsection{Mapping between the Maturity Models and External Best Practices}

Table 4 summarizes the mapping between the maturity stages of each maturity model and the external best practice subcategories. The 'BP subcategories' column represents the external best practice subcategories described in Table VIII in the Appendix.

Table 4. Mapping between Maturity Stages and External Best Practice Subcategories

\begin{tabular}{|l|l|l|l|l|l|}
\hline $\begin{array}{l}\text { BP } \\
\text { Subcategories }\end{array}$ & Stage 1 & Stage 2 & Stage 3 & Stage 4 & Stage 5 and above \\
\hline $\begin{array}{l}\text { E-participation } \\
\text { NA }\end{array}$ & $\begin{array}{l}{[8],[12],[17],[18],} \\
{[20],[22],[28]}\end{array}$ & $\begin{array}{l}{[9],[13],[14],} \\
{[22],[24],[32]}\end{array}$ & $\begin{array}{l}{[9],[16],} \\
{[22],[30]}\end{array}$ & $\begin{array}{l}{[12],[13],[17],[21],[23],} \\
{[22],[24],[26],[32]}\end{array}$ \\
\hline Advertising & NA & NA & NA & {$[30]$} & NA \\
\hline Referencing & NA & NA & NA & NA & NA \\
\hline Incentives & NA & NA & NA & NA & NA \\
\hline Contests & NA & NA & NA & {$[22]$} & NA \\
\hline
\end{tabular}

From the above it can be concluded that the maturity models address only some of the external best practice subcategories and no model is covering all these subcategories. Moreover, two best practice subcategories are not covered by any maturity model, this includes: referencing and incentives. Besides that, some authors raise the same best practice in different stages with more sophistication in higher stages.

\section{Synthesis and Discussion of the Mapping}

From the mapping conducted in the previous section, a set of findings has been raised. Fig. 2 shows the total number of the covered best practice subcategories (including back-end, Web design, Web content and external subcategories) for each maturity model. As shown in the Figure, out of 35 best practice subcategories of the best practice model, Lee and Kwak maturity model covers the greatest number of 
subcategories with 13 subcategories, followed by United Nations and Windley with 11 subcategories. Almazan and Garcia maturity model covers 10 subcategories. Besides, Wescott, Deloitte and Touche, and Siau and Long maturity models cover 9 subcategories. Moreover, UK, West, Gartner and Hiller and Belanger maturity models cover 8 subcategories. In addition, Accenture, Shahkooh and Cisco maturity models cover 7 subcategories. Furthermore, Kim and Grant, Moon, Andersen and Henriksen and Layne and Lee maturity models cover 5 subcategories. Besides that, Netchaeva, World Bank and Alhomod maturity models cover 4 subcategories. Then, Chandler and Emanuel along with Howard cover 3 subcategories. Finally, Reddick and Chen are in the last position with 2 covered subcategories.

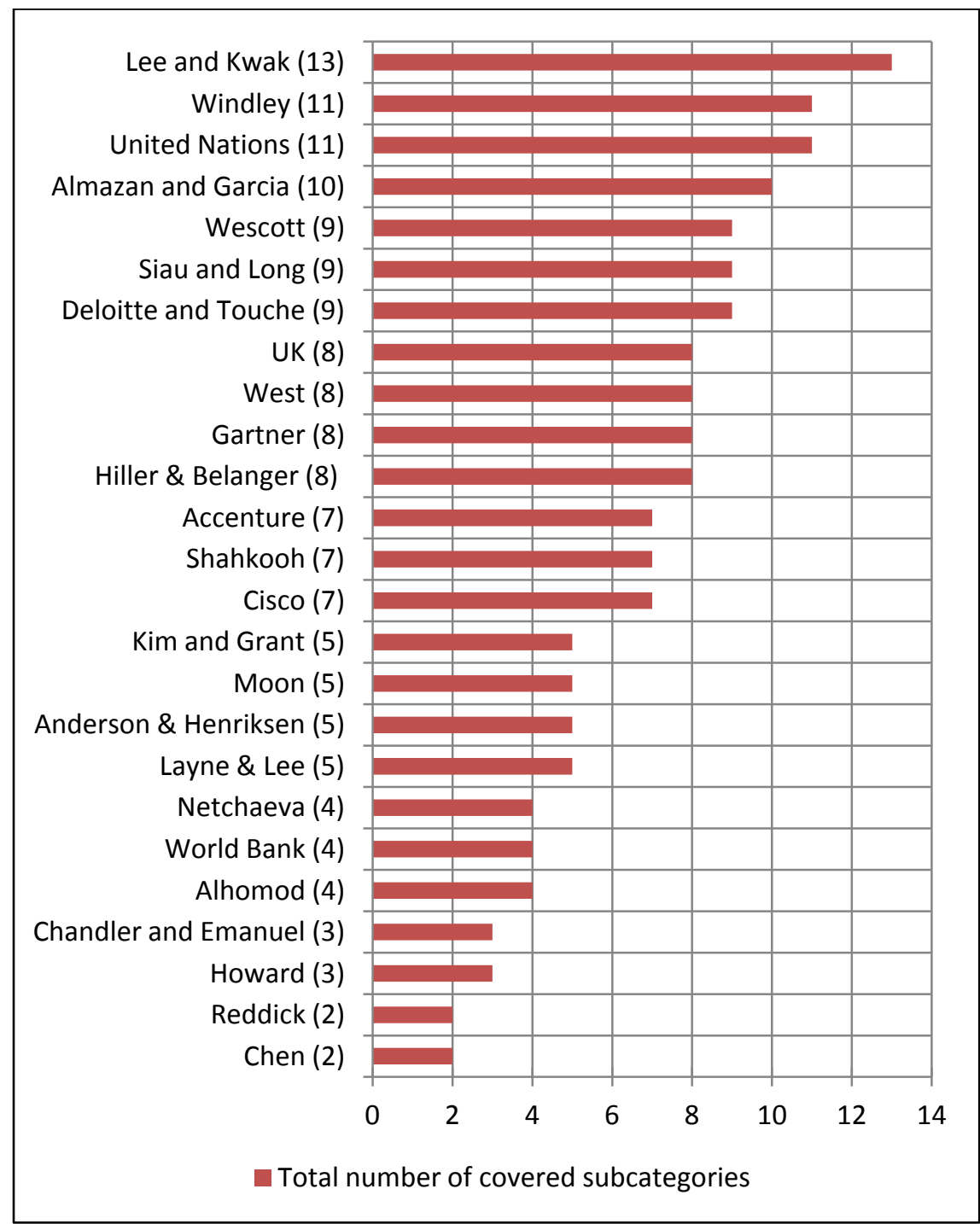

Fig. 2. Number of covered subcategories for each maturity models.

Fig. 3 shows the number of covered subcategories for each category type (back-end, front-end and external) with respect to each maturity model. From Fig. 3, it can be noticed that for:

- "Back-end subcategories"; Windley and Deloitte and Touche maturity models are covering the greatest number of back-end subcategories which is 6 subcategories. On the other hand, West maturity model does not cover any back-end subcategory.

- "Design subcategories"; Siau and Long maturity model covers the greatest number of design subcategories which is 3 subcategories. On the other hand, Accenture, Kim and Grant, and Chandler 
and Emanuel maturity models are not covering any design subcategory.

- "Content subcategories"; although West maturity model is not covering many back-end subcategories, it is the model that covers the greatest number of content subcategories which is 5 subcategories. On the other hand, Netchaeva, Accenture, Reddick, Chen, Chandler and Emanuel, Shahkooh, Howard, Moon, Cisco, Alhomod and Layne and Lee maturity models do not cover any content subcategory.

- "External subcategories"; Lee and Kwak and Accenture maturity models cover the greatest number of external subcategories which is 2 subcategories. On the other hand, UK, Reddick, Chen, Chandler and Emanuel, Deloitte and Touche, Gartner, Alhomod and Andersen and Henriksen maturity models do not cover any external subcategory.

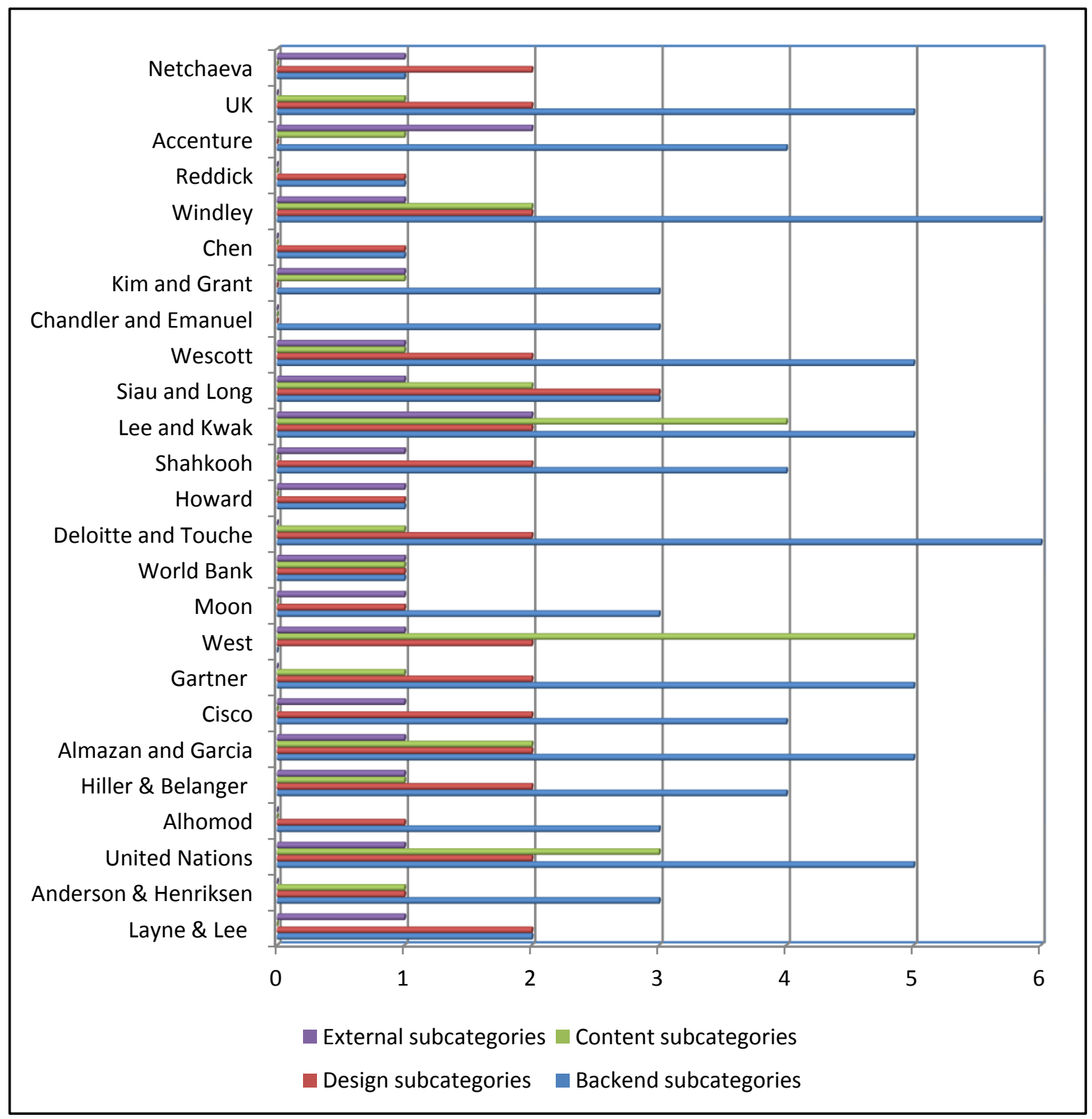

Fig. 3. Covered best practice subcategories of each maturity model.

To sum up, although the maturity models were proposed for different purposes, they are all composed of a set of stages that contain best practices in order to rank the portals' maturity. However, regarding the maturity models' best practices coverage, it is clear from the mapping performed in the previous section 
that none of the maturity models are covering all the e-government portals' best practices of the eGPBPM. Table 5 provides a summary of the 12 best practice subcategories that are not covered by any maturity model among the 25 models. Besides that, some of the e-government maturity models are covering only few e-government portals' best practices. Furthermore, the focus of the maturity models is not balanced and does not include all the pillars of e-government portals' best practices (back-end, Web design, Web content and external). For instance, many maturity models focus on one best practice category such as back-end or Web content and ignore other categories. Therefore, the output of the mapping will be an important input to give guidelines to build a new maturity model that should cover all the e-government portals' best practices from the literature. Besides that, it allows us to figure out the most appropriate stage of maturity for each best practice subcategory.

Table 5. The best Practice Subcategories not Covered by any Maturity Model

\begin{tabular}{|l|l|}
\hline Best practice category & Best Practice subcategory \\
\hline Back-end & Use of standards \\
& Modularity \\
& Delegation \\
& Reusability \\
& Responsiveness \\
\hline Web design & Industrialization \\
& Structuration \\
\hline Web content & Interactive games \\
& Mobile apps \\
& Understandability \\
\hline External & Referencing \\
& Incentives \\
\hline
\end{tabular}

\section{Conclusion}

In this paper, we have identified to which extent the e-government maturity models are covering the best practices of the eGPBPM. To achieve this goal, a detailed mapping between the eGPBPM [1] and the best practices of the 25 maturity models has been completed.

To perform this mapping, the best practices of 25 maturity models were collected after an extensive literature review in [7]. Although, the maturity models present large similarities between them in terms of stage names, it seems that their features differ widely. Second, we have collected e-government portals' best practices to build a best practice model after an extensive literature review in [1]. The model is composed of four best practice categories, including: back-end, Web design, Web content and external. Each best practice category contains subcategories, and each subcategory contains best practices.

After the mapping, it was noticed that none of the maturity models is covering all the best practice subcategories of the eGPBPM. Moreover, all the maturity models miss at least half of the best practices of the eGPBPM. Besides that, some maturity models are covering only few e-government portals' best practices such as: Chandler and Emanuel, and Howard that cover 3 subcategories and Reddick and Chen that cover 2 subcategories. Furthermore, the focus of the maturity models in terms of best practice categories is not balanced and does not include all the pillars of e-government portals' (back-end, Web design, Web content and external). For instance, some maturity models focus on one best practice category, while they ignore the other categories such as: West (ignores all the back-end subcategories), Accenture, Kim and Grant, Chandler and Emanuel (ignore all the Web design subcategories), Netchaeva, Accenture, Reddick, Chen, Chandler and Emanuel, Shahkooh, Howard, Moon, Cisco, Alhomod, Layne and Lee (ignore all the Web content subcategories), UK, Reddick, Chen, Chandler and Emanuel, Deloitte and Touche, Gartner, Alhomod, and Andersen and Henriksen maturity models (ignore all the external subcategories). 
As a future work, the output of this mapping triggers recommendations and guidelines in order to build an e-government portals maturity model that includes all the e-government portals' best practices of the eGPBPM [1]. Besides that, the mapping between the maturity models and the best practice model will allow us to build the new maturity model, since it allows us to figure out the most appropriate stage of maturity for each best practice subcategory.

\section{Appendix}

Table I. Summary of the Maturity Models best Practices with 2 and 3 Stages

\begin{tabular}{|c|c|c|c|}
\hline Stage & Stage 1 & Stage 2 & Stage 3 \\
\hline Cisco & $\begin{array}{l}\text { - Legislative posting } \\
\text { - Public notices } \\
\text { - Online forms } \\
\text { - Webcasting } \\
\text { - Personalized portals }\end{array}$ & $\begin{array}{l}\text { - Citizen self-service portal } \\
\text { - Electronic payments }\end{array}$ & $\begin{array}{l}\text { - Services consolidated and shared across } \\
\text { various government jurisdictions } \\
\text { - Personalization } \\
\text { - Interactive communication } \\
\text { - Identity management } \\
\text { - Content security }\end{array}$ \\
\hline $\begin{array}{l}\text { World } \\
\text { Bank }\end{array}$ & $\begin{array}{l}\text { - Variety of information } \\
\text { - Rules, regulations, } \\
\text { documents and forms }\end{array}$ & $\begin{array}{l}\text { - Feedback and comments on } \\
\text { legislatives or policy proposals } \\
\text { - E-mail contacts of officials }\end{array}$ & $\begin{array}{l}\text { - Users can complete transactions online } \\
\text { - Security }\end{array}$ \\
\hline Howard & $\begin{array}{l}\text { - Information about } \\
\text { government its } \\
\text { activities }\end{array}$ & $\begin{array}{l}\text { - Interaction } \\
\text { - E-mails } \\
\text { - Chat rooms }\end{array}$ & $\begin{array}{l}\text { - Users can complete transactions } \\
\text { - Payments }\end{array}$ \\
\hline Chen & $\begin{array}{l}\text { - Presentation catalogue } \\
\text { - Downloadable forms }\end{array}$ & $\begin{array}{l}\text { - Working databases } \\
\text { - Online transactions } \\
\text { - Online forms }\end{array}$ & - Vertical integration \\
\hline Reddick & $\begin{array}{l}\text { - Information available } \\
\text { online }\end{array}$ & $\begin{array}{l}\text { - Online transactions } \\
\text { - Electronic payments } \\
\text { - Online databases } \\
\text { - One stop shops }\end{array}$ & NA \\
\hline
\end{tabular}

Table II. Summary of the Maturity Models Best Practices with 4 Stages

\begin{tabular}{|c|c|c|c|c|}
\hline MM & Stage 1 & Stage 2 & Stage 3 & Stage 4 \\
\hline $\begin{array}{l}\text { Layne and } \\
\text { Lee }\end{array}$ & $\begin{array}{l}\text { - Present on the web } \\
\text { - Download forms } \\
\text { - Consult presentation } \\
\text { catalog }\end{array}$ & $\begin{array}{l}\text { - Make transactions } \\
\text { - Fill forms with a } \\
\text { confirmation of } \\
\text { receipt } \\
\text { - Online working } \\
\text { databases } \\
\text { - Talk to officials } \\
\text { - Online forums } \\
\text { - E-participation }\end{array}$ & $\begin{array}{l}\text { - Integration to higher } \\
\text { stage systems } \\
\text { - Within similar } \\
\text { functionalities }\end{array}$ & $\begin{array}{l}\text { - Systems integrated across various } \\
\text { jurisdictions } \\
\text { - Portals are real one stop shops }\end{array}$ \\
\hline $\begin{array}{l}\text { Andersen } \\
\text { and } \\
\text { Henriksen }\end{array}$ & $\begin{array}{l}\text { - Horizontal and } \\
\text { vertical integration } \\
\text { - Use of intranet } \\
\text { - Limited use of } \\
\text { front-end systems } \\
\text { - Self-service like } \\
\text { downloadable files }\end{array}$ & $\begin{array}{l}\text { - Extensive use of } \\
\text { intranet } \\
\text { - Personalized Web } \\
\text { interfaces } \\
\text { according to } \\
\text { users' needs } \\
\text { - Extensive use of } \\
\text { intranet. }\end{array}$ & $\begin{array}{l}\text { - Abandoning of } \\
\text { intranet } \\
\text { - Transparent } \\
\text { processes } \\
\text { - Personalized Web } \\
\text { interfaces } \\
\text { - The Web site is fed by } \\
\text { information from } \\
\text { other institutions. } \\
\text { - Information is not } \\
\text { organization oriented } \\
\text { - The Web site is } \\
\text { organized to solve } \\
\text { citizens' problems }\end{array}$ & $\begin{array}{l}\text { - Data mobility, data can be shared } \\
\text { between organizations } \\
\text { - Application mobility } \\
\text { - Ownership to data is transferred to } \\
\text { the customers } \\
\text { - Customer centricity is widely } \\
\text { applied }\end{array}$ \\
\hline UN & $\begin{array}{l}\text { - Web sites contain } \\
\text { Static information } \\
\text { - Web sites contain } \\
\text { links to ministries }\end{array}$ & $\begin{array}{l}\text { - One way } \\
\text { communication } \\
\text { - Downloadable } \\
\text { forms }\end{array}$ & $\begin{array}{l}\text { - Two way interaction } \\
\text { with citizen } \\
\text { - E-voting } \\
\text { - Citizen identity }\end{array}$ & $\begin{array}{l}\text { - Web sites are proactive } \\
\text { - Citizen feedback } \\
\text { - Web 2.0 } \\
\text { - Agencies are citizen centric }\end{array}$ \\
\hline
\end{tabular}




\begin{tabular}{|c|c|c|c|c|}
\hline MM & Stage 1 & Stage 2 & Stage 3 & Stage 4 \\
\hline & $\begin{array}{l}\text { and other } \\
\text { government } \\
\text { branches } \\
\text { - Laws, regulations, } \\
\text { relevant } \\
\text { documentation and } \\
\text { information on } \\
\text { public policy } \\
\end{array}$ & $\begin{array}{l}\text { - The portal } \\
\text { features audio } \\
\text { and video clips } \\
\text { and are } \\
\text { multilingual }\end{array}$ & $\begin{array}{l}\text { - Applying for } \\
\text { certificates, licenses } \\
\text { and permits } \\
\text { - Secure online } \\
\text { payments }\end{array}$ & $\begin{array}{l}\text { - Services organized in a through life } \\
\text { events or segmented groups } \\
\text { - Citizens involved activities and } \\
\text { decision making (e-participation) } \\
\text { - Data is transferred through } \\
\text { integrated applications }\end{array}$ \\
\hline Alhomod & $\begin{array}{l}\text { - Portal provides only } \\
\text { information }\end{array}$ & $\begin{array}{l}\text { - Citizen can } \\
\text { download forms } \\
\text { and email them }\end{array}$ & $\begin{array}{l}\text { - Users can complete } \\
\text { entire tasks } \\
\text { - Possibility of } \\
\text { payments }\end{array}$ & $\begin{array}{l}\text { - Various departments shares } \\
\text { information }\end{array}$ \\
\hline Gartner & $\begin{array}{l}\text { - Web site is static } \\
\text { - Basic information }\end{array}$ & $\begin{array}{l}\text { - Search engines } \\
\text { - Document } \\
\text { downloading } \\
\text { - Emails }\end{array}$ & $\begin{array}{l}\text { - Complete transaction } \\
\text { online } \\
\text { - Payment } \\
\text { - Security } \\
\text { - Privacy }\end{array}$ & $\begin{array}{l}\text { - Integration } \\
\text { - Personalization }\end{array}$ \\
\hline West & $\begin{array}{l}\text { - Web sites used for } \\
\text { posting information } \\
\text { - Publications, } \\
\text { databases, reports } \\
\text { and legislations }\end{array}$ & $\begin{array}{l}\text { - Search engines } \\
\text { - Privacy and } \\
\text { security } \\
\text { statements are } \\
\text { few }\end{array}$ & $\begin{array}{l}\text { - One stop shop portal } \\
\text { - Variety of services are } \\
\text { available } \\
\text { - Privacy and security } \\
\text { policies } \\
\text { - Translations } \\
\text { - The portal is } \\
\text { accessible for people } \\
\text { with disabilities }\end{array}$ & $\begin{array}{l}\text { - Personalization } \\
\text { - Push technology (email } \\
\text { subscriptions and newsletters) } \\
\text { - Feedback and comments }\end{array}$ \\
\hline $\begin{array}{l}\text { Chandler } \\
\text { and } \\
\text { Emanuel }\end{array}$ & - Online information & $\begin{array}{l}\text { - Basic interaction } \\
\text { - Email systems }\end{array}$ & - Online transaction & $\begin{array}{l}\text { - Integrated services across various } \\
\text { departments and agencies. }\end{array}$ \\
\hline Windley & $\begin{array}{l}\text { - Static pages } \\
\text { - Downloadable forms } \\
\text { - Policy statements } \\
\text { - Contact information } \\
\text { - Phone numbers }\end{array}$ & $\begin{array}{l}\text { - Interactions } \\
\text { mechanisms } \\
\text { - Emails } \\
\text { - Web forms } \\
\text { - Help } \\
\text { - FAQs } \\
\text { - Electronic } \\
\text { payments } \\
\text { - Surveys } \\
\end{array}$ & $\begin{array}{l}\text { - End to end } \\
\text { transactions } \\
\text { - Information is shared } \\
\text { between } \\
\text { organizations }\end{array}$ & $\begin{array}{l}\text { - Services are customer centric } \\
\text { - Services are segmented according to } \\
\text { population groups and life events } \\
\text { - Web forms } \\
\text { - Workflows } \\
\text { - Security } \\
\text { - Electronic payments } \\
\text { - Vertical and horizontal integration }\end{array}$ \\
\hline
\end{tabular}

Table III. Summary of the Maturity Models Best Practices with 5 Stages

\begin{tabular}{|c|c|c|c|c|c|}
\hline MM Stage & Stage 1 & Stage 2 & Stage 3 & Stage 4 & Stage 5 \\
\hline $\begin{array}{l}\text { Hiller and } \\
\text { Belanger }\end{array}$ & $\begin{array}{l}\text { - Posting } \\
\text { information } \\
\text { - Information } \\
\text { accurate and } \\
\text { timely. }\end{array}$ & $\begin{array}{l}\text { - Communication } \\
\text { between the } \\
\text { citizens and the } \\
\text { government } \\
\text { - E-mail systems } \\
\text { - Citizens can fill in } \\
\text { information } \\
\text { request }\end{array}$ & $\begin{array}{l}\text { - Online services } \\
\text { - Financial transactions } \\
\text { - Transactions can be } \\
\text { completed online }\end{array}$ & $\begin{array}{l}\text { - Services are } \\
\text { connected } \\
\text { internally and } \\
\text { externally } \\
\text { - A single portal } \\
\text { can be used to } \\
\text { access all } \\
\text { e-government } \\
\text { services }\end{array}$ & $\begin{array}{l}\text { - Political } \\
\text { participation } \\
\text { - Online } \\
\text { voting } \\
\text { - Posting } \\
\text { comments } \\
\text { online } \\
\text { - Privacy } \\
\text { should be } \\
\text { supported }\end{array}$ \\
\hline Moon & $\begin{array}{l}\text { - Posting data } \\
\text { and } \\
\text { information }\end{array}$ & $\begin{array}{l}\text { - Interactive mode } \\
\text { between the } \\
\text { governments and } \\
\text { the stakeholders } \\
\text { - Email systems }\end{array}$ & $\begin{array}{l}\text { - Self-services like renewing } \\
\text { licenses } \\
\text { - Payments }\end{array}$ & $\begin{array}{l}\text { - Horizontal and } \\
\text { vertical } \\
\text { integration } \\
\text { - Data sharing } \\
\text { between various } \\
\text { departments } \\
\text { enhances } \\
\text { effectiveness, } \\
\text { user-friendlines } \\
\text { s and efficiency }\end{array}$ & $\begin{array}{l}\text { - Surveys } \\
\text { - Forums } \\
\text { - Online } \\
\text { voting }\end{array}$ \\
\hline Shahkooh & - Information is & - Emailing officials & - Users can conduct secure & - Single point of & - Online \\
\hline
\end{tabular}




\begin{tabular}{|c|c|c|c|c|c|}
\hline MM Stage & Stage 1 & Stage 2 & Stage 3 & Stage 4 & Stage 5 \\
\hline et al & $\begin{array}{l}\text { published } \\
\text { online }\end{array}$ & $\begin{array}{l}\text { - Downloading } \\
\text { forms }\end{array}$ & $\begin{array}{l}\text { transactions } \\
\text { - Security } \\
\text { - Payments } \\
\text { - Digital signatures }\end{array}$ & contact & $\begin{array}{l}\text { voting, } \\
\text { - Public } \\
\text { forums } \\
\text { - Opinion } \\
\text { surveys }\end{array}$ \\
\hline $\begin{array}{l}\text { Lee and } \\
\text { Kwak }\end{array}$ & $\begin{array}{l}\text { - Broadcasting } \\
\text { information } \\
\text { - Governments } \\
\text { measure the } \\
\text { number of } \\
\text { visitors and } \\
\text { pages viewed } \\
\text { to assess the } \\
\text { performance }\end{array}$ & $\begin{array}{l}\text { - Use of social media } \\
\text { is limited } \\
\text { - Feedback is get } \\
\text { from the public } \\
\text { - Publishing } \\
\text { relevant data } \\
\text { online in a timely } \\
\text { manner } \\
\text { - Data quality and } \\
\text { accuracy is } \\
\text { increased } \\
\text { - Privacy standards } \\
\text { - Governments } \\
\text { measure the } \\
\text { number of } \\
\text { published } \\
\text { datasets, the } \\
\text { number of data } \\
\text { downloads, and } \\
\text { the number of } \\
\text { visitors to evaluate } \\
\text { Web site } \\
\text { performance }\end{array}$ & $\begin{array}{l}\text { - Social media tools } \\
\text { - Input from the public is } \\
\text { welcomed } \\
\text { - Feedback used in policy } \\
\text { decisions which helps } \\
\text { governments make reliable } \\
\text { decisions } \\
\text { - Respond to public's } \\
\text { feedback } \\
\text { - E-Voting and e-Petitioning } \\
\text { - Social media: } \\
\text { Facebook, Twitter, } \\
\text { YouTube, and Flickr } \\
\text { - Web } 2.0 \text { tools to share } \\
\text { comments, stories and ideas } \\
\text { - Data privacy } \\
\text { - Security } \\
\text { - Governments measure the } \\
\text { stage of public participation } \\
\text { using process centered } \\
\text { metrics to asses } \\
\text { performance }\end{array}$ & $\begin{array}{l}\text { - Interagency } \\
\text { collaboration by } \\
\text { sharing data and } \\
\text { public input } \\
\text { - Public contests } \\
\text { - Shared } \\
\text { repositories are } \\
\text { made available } \\
\text { - Data is analyzed } \\
\text { for obtaining } \\
\text { new insights } \\
\text { and improving } \\
\text { decision-making }\end{array}$ & $\begin{array}{l}\text { - Data is easily } \\
\text { accessed by } \\
\text { mobile } \\
\text { devices and } \\
\text { tablets } \\
\text { - Portals and } \\
\text { social media } \\
\text { sites are } \\
\text { compatible } \\
\text { with various } \\
\text { platforms } \\
\text { - Data is } \\
\text { vertically } \\
\text { and } \\
\text { horizontally } \\
\text { integrated } \\
\text { - Data, social } \\
\text { media tools } \\
\text { and services } \\
\text { are } \\
\text { integrated } \\
\text { - Ease of } \\
\text { navigation, } \\
\text { Single sign } \\
\text { on } \\
\text { - Data } \\
\text { analytics is } \\
\text { used for } \\
\text { decision } \\
\text { making } \\
\text { processes } \\
\text { - Agencies are } \\
\text { focused on } \\
\text { enabling } \\
\text { continuous } \\
\text { improvemen } \\
\text { ts and } \\
\text { innovation } \\
\text { of public } \\
\text { engagement } \\
\text { programs }\end{array}$ \\
\hline $\begin{array}{l}\text { Siau and } \\
\text { Long }\end{array}$ & $\begin{array}{l}\text { - Static } \\
\text { information } \\
\text { - Information } \\
\text { regularly } \\
\text { updated }\end{array}$ & $\begin{array}{l}\text { - Form download } \\
\text { - Search engines } \\
\text { - Email systems }\end{array}$ & $\begin{array}{l}\text { - Users can perform complete } \\
\text { transactions } \\
\text { - Payments } \\
\text { - Personal information } \\
\text { updates }\end{array}$ & $\begin{array}{l}\text { - Vertical and } \\
\text { horizontal } \\
\text { integration } \\
\text { - Single unified } \\
\text { portal }\end{array}$ & $\begin{array}{l}\text { - Online } \\
\text { voting } \\
\text { - Polling } \\
\text { - Surveys } \\
\text { - Contribution } \\
\text { on political } \\
\text { decisions }\end{array}$ \\
\hline $\begin{array}{l}\text { Kim and } \\
\text { Grant }\end{array}$ & $\begin{array}{l}\text { - Limited } \\
\text { information } \\
\text { available on } \\
\text { the web }\end{array}$ & $\begin{array}{l}\text { - Search engines } \\
\text { - Downloadable } \\
\text { forms }\end{array}$ & $\begin{array}{l}\text { - Online transactions } \\
\text { - Electronic payments }\end{array}$ & $\begin{array}{l}\text { - Horizontal and } \\
\text { vertical } \\
\text { integration } \\
\text { - Measurement of } \\
\text { performance }\end{array}$ & $\begin{array}{l}\text { - Political } \\
\text { activities } \\
\text { - Continuous } \\
\text { improvemen } \\
\text { ts }\end{array}$ \\
\hline Accenture & $\begin{array}{l}\text { - Information is } \\
\text { published } \\
\text { online }\end{array}$ & $\begin{array}{l}\text { - Security } \\
\text { - Online presence is } \\
\text { broad }\end{array}$ & $\begin{array}{l}\text { - Many services are available } \\
\text { - Cross agency cooperation } \\
\text { - Services are customer } \\
\text { centric }\end{array}$ & $\begin{array}{l}\text { - Services are } \\
\text { clustered } \\
\text { - Clear ownership } \\
\text { and authority } \\
\text { - CIO or central }\end{array}$ & $\begin{array}{l}\text { - Improved } \\
\text { customer } \\
\text { service } \\
\text { delivery } \\
\text { - Multichannel }\end{array}$ \\
\hline
\end{tabular}




\begin{tabular}{|c|c|c|c|c|c|}
\hline MM Stage & Stage 1 & Stage 2 & Stage 3 & Stage 4 & Stage 5 \\
\hline & & & & $\begin{array}{l}\text { agency } \\
\text { - Customer is } \\
\text { involved in the } \\
\text { process of } \\
\text { e-government } \\
\text { - The services } \\
\text { are marketed }\end{array}$ & integration \\
\hline UK & $\begin{array}{l}\text { - Few pages are } \\
\text { available } \\
\text { - Basic } \\
\text { information } \\
\text { about the } \\
\text { agency }\end{array}$ & $\begin{array}{l}\text { - Web site contains } \\
\text { many pages } \\
\text { - Downloadable } \\
\text { forms }\end{array}$ & $\begin{array}{l}\text { - Personalization options } \\
\text { - Customizable search tools } \\
\text { - Extensive use of emails } \\
\text { - Timely responses of mails } \\
\text { - Email alerts }\end{array}$ & $\begin{array}{l}\text { - Secure } \\
\text { transactions } \\
\text { - Payments } \\
\text { - Users can } \\
\text { authenticate } \\
\text { - Users can track } \\
\text { the status of } \\
\text { their } \\
\text { applications } \\
\text { - Users can } \\
\text { manage their } \\
\text { own accounts }\end{array}$ & $\begin{array}{l}\text { - One stop } \\
\text { shops } \\
\text { - Vertical and } \\
\text { Horizontal } \\
\text { integration } \\
\text { - Agency } \\
\text { anticipate } \\
\text { the needs of } \\
\text { users and } \\
\text { alert them }\end{array}$ \\
\hline Netchaeva & $\begin{array}{l}\text { - Online Web } \\
\text { sites } \\
\text { - Department } \\
\text { information }\end{array}$ & $\begin{array}{l}\text { FAQs } \\
\text { - Email systems }\end{array}$ & $\begin{array}{l}\text { - Forums } \\
\text { - Opinion surveys }\end{array}$ & $\begin{array}{l}\text { - Online services } \\
\text { - Electronic } \\
\text { payments }\end{array}$ & $\begin{array}{l}\text { - One stop } \\
\text { shop } \\
\text { - Votes } \\
\text { - Online } \\
\text { discussion } \\
\text { - Comment on } \\
\text { policy and } \\
\text { legislation } \\
\text { proposals } \\
\end{array}$ \\
\hline
\end{tabular}

Table IV. Summary of the Maturity Models Best Practices with 6 Stages

\begin{tabular}{|c|c|c|c|c|c|c|}
\hline $\begin{array}{l}\text { MM } \\
\text { Stage }\end{array}$ & Stage 1 & Stage 2 & Stage 3 & Stage 4 & Stage 5 & Stage 6 \\
\hline $\begin{array}{l}\text { Almazan and } \\
\text { Gil-Garcia }\end{array}$ & $\begin{array}{l}\text { - Web site } \\
\text { contain } \\
\text { static and } \\
\text { limited } \\
\text { informatio } \\
\text { n }\end{array}$ & $\begin{array}{l}\text { - Information is } \\
\text { frequently } \\
\text { updated } \\
\text { - More pages } \\
\text { available }\end{array}$ & $\begin{array}{l}\text { - Download } \\
\text { forms } \\
\text { - Communicate } \\
\text { with the } \\
\text { government by } \\
\text { mail } \\
\text { - Customization } \\
\text { according to } \\
\text { user profiles } \\
\text { - Forums } \\
\text { - Chats } \\
\text { - Search engines }\end{array}$ & $\begin{array}{l}\text { - Secure online } \\
\text { Web services } \\
\text { - Payments } \\
\text { - User centric } \\
\text { approach } \\
\text { - Advanced } \\
\text { customization } \\
\text { according to } \\
\text { user profiles }\end{array}$ & $\begin{array}{l}\text { - One stop } \\
\text { shop } \\
\text { - One entry } \\
\text { portal of } \\
\text { different - } \\
\text { Jurisdiction } \\
\text { agencies }\end{array}$ & $\begin{array}{l}\text { - Voting } \\
\text { - Opinion } \\
\text { surveys } \\
\text { Public } \\
\text { forums }\end{array}$ \\
\hline $\begin{array}{l}\text { Deloitte and } \\
\text { Touche }\end{array}$ & $\begin{array}{l}\text { - Static } \\
\text { informatio } \\
\mathrm{n} \\
\text { - Electronic } \\
\text { encycloped } \\
\text { ia }\end{array}$ & $\begin{array}{l}\text { - Transaction } \\
\text { - Exchange of } \\
\text { information } \\
\text { - Digital } \\
\text { signatures } \\
\text { - Citizens' } \\
\text { records are } \\
\text { kept } \\
\text { confidential } \\
\text { - Payments }\end{array}$ & $\begin{array}{l}\text { - Single point of } \\
\text { entry portal } \\
\text { - Portals are } \\
\text { citizen centric } \\
\text { - Payments }\end{array}$ & $\begin{array}{l}\text { - Portal can be } \\
\text { personalized } \\
\text { - Interfaces at } \\
\text { this stage can } \\
\text { be manipulated } \\
\text { by users }\end{array}$ & $\begin{array}{l}\text { - Services are } \\
\text { clustered to } \\
\text { provide } \\
\text { unified } \\
\text { services to } \\
\text { the customer } \\
\text { - Services are } \\
\text { considered } \\
\text { as a group of } \\
\text { transactions } \\
\text { rather than a } \\
\text { group of } \\
\text { agencies }\end{array}$ & $\begin{array}{l}\text { - Portal is } \\
\text { integrated } \\
\text { - Services are } \\
\text { personalize } \\
\text { d to } \\
\text { customer } \\
\text { needs }\end{array}$ \\
\hline Wescott & $\begin{array}{l}\text { - E-mail } \\
\text { systems } \\
\text { - G2G } \\
\text { systems }\end{array}$ & $\begin{array}{l}\text { - Workflow } \\
\text { systems } \\
\text { - Information is } \\
\text { department } \\
\text { centric } \\
\text { - Public can }\end{array}$ & $\begin{array}{l}\text { - Online } \\
\text { services } \\
\text { - Laws and } \\
\text { regulations } \\
\text { - Emails, } \\
\text { telephone and }\end{array}$ & $\begin{array}{l}\text { - Secure } \\
\text { payments } \\
\text { - License } \\
\text { renewals }\end{array}$ & $\begin{array}{l}\text { - Votes } \\
\text { - Opinions } \\
\text { - Feedback }\end{array}$ & $\begin{array}{l}\text { - Vertical } \\
\text { and } \\
\text { horizontal } \\
\text { integration } \\
\text { - FAQs } \\
\text { - Payments }\end{array}$ \\
\hline
\end{tabular}




\begin{tabular}{|c|c|c|c|c|c|c|}
\hline MM $\quad$ Stage & Stage 1 & Stage 2 & Stage 3 & Stage 4 & Stage 5 & Stage 6 \\
\hline & & $\begin{array}{l}\text { access } \\
\text { information }\end{array}$ & $\begin{array}{l}\text { fax numbers } \\
\text { - Suggestions } \\
\text { using email } \\
\text { - Forums to ask } \\
\text { questions and } \\
\text { receive } \\
\text { answers }\end{array}$ & & & $\begin{array}{l}\text { - One stop } \\
\text { shops } \\
\text { - Sharing of } \\
\text { information } \\
\text { between } \\
\text { agencies }\end{array}$ \\
\hline
\end{tabular}

Table V. Summary of Back-end Best Practices

\begin{tabular}{|c|c|c|c|}
\hline Subcategory & Details & Advantages & Examples \\
\hline Customer Centricity & $\begin{array}{l}\text { - Make services customer-centric, } \\
\text { tailor-made and designed with "its } \\
\text { users in mind" }\end{array}$ & $\begin{array}{l}\text { - User does not need to be } \\
\text { aware of all existing } \\
\text { organizations } \\
\text { - Enable the ease of use and } \\
\text { usefulness } \\
\text { - Enable efficiency }\end{array}$ & $\begin{array}{l}\text { - One stop shops and one } \\
\text { agency feel portals } \\
\text { - Observatory methods or } \\
\text { ethnographic work } \\
\text { - Living labs }\end{array}$ \\
\hline $\begin{array}{l}\text { Interoperability } \\
\text { (Vertical and } \\
\text { Horizontal) }\end{array}$ & $\begin{array}{l}\text { - Vertical integration: between } \\
\text { different departments; federal, } \\
\text { provincial and municipal within the } \\
\text { same jurisdiction } \\
\text { - Horizontal integration: between } \\
\text { various jurisdictions of the } \\
\text { government. }\end{array}$ & $\begin{array}{l}\text { - Help making services } \\
\text { customer centric } \\
\text { - Enable one stop access } \\
\text { - Absence of delays }\end{array}$ & $\begin{array}{l}\text { - X-Road in Estonia } \\
\text { - The electronic file system } \\
\text { in Austria }\end{array}$ \\
\hline Use of standards & $\begin{array}{l}\text { - Use of standards and open source } \\
\text { standards }\end{array}$ & $\begin{array}{l}\text { - Enable cross platform } \\
\text { interoperability and } \\
\text { facilitate interoperability } \\
\text { efforts } \\
\text { - Can achieve flexibility and } \\
\text { ease of change in } \\
\text { requirements and } \\
\text { technology } \\
\text { - Helps preventing the fact of } \\
\text { "re-architecting" as } \\
\text { problems arise } \\
\text { - Reinforces coordination }\end{array}$ & $\begin{array}{l}\text { XML } \\
\text { - SOAP }\end{array}$ \\
\hline Modularity & - Implement the modules one by one & $\begin{array}{l}\text { - Helps in reusing services or } \\
\text { components } \\
\text { - Achieve flexibility and } \\
\text { interoperability } \\
\text { - Changing small } \\
\text { functionalities does not } \\
\text { break the whole } \\
\text { functionality }\end{array}$ & - SOA \\
\hline Security & $\begin{array}{l}\text { - Allow citizens to make transactions } \\
\text { securely } \\
\text { - Disaster recovery and real time } \\
\text { backup }\end{array}$ & $\begin{array}{l}\text { - Increase adoption and trust } \\
\text { - Text-based signatures, can } \\
\text { be printed } \\
\text { - Digital signature will allow } \\
\text { complex transactions to be } \\
\text { done electronically }\end{array}$ & $\begin{array}{l}\text { - Digital signatures for } \\
\text { identification, } \\
\text { authentication and } \\
\text { security }\end{array}$ \\
\hline Privacy & - keep citizens' records confidential & - Increase adoption and trust & $\begin{array}{l}\text { - Role based access of } \\
\text { e-government employees } \\
\text { - P3P compliance } \\
\text { - Avoid Cookies } \\
\text { - Avoid use of HTML get } \\
\text { forms }\end{array}$ \\
\hline Delegation & $\begin{array}{l}\text { - Allow someone to act on behalf of a } \\
\text { person or company }\end{array}$ & $\begin{array}{l}\text { - Allows more flexibility for } \\
\text { citizens }\end{array}$ & $\begin{array}{l}\text { - Austria have mechanisms } \\
\text { supporting delegation }\end{array}$ \\
\hline Single Sign on & - Single authentication & $\begin{array}{l}\text { - Users can log in to many } \\
\text { application only one time }\end{array}$ & $\begin{array}{l}\text { - The Seychelles's integrated } \\
\text { portal in eastern Africa } \\
\text { offers a single sign on to its } \\
\text { users }\end{array}$ \\
\hline
\end{tabular}




\begin{tabular}{|c|c|c|c|}
\hline Reusability & $\begin{array}{l}\text { - Before starting the development of a } \\
\text { new module, one should check the } \\
\text { possibility of Web } 2.0 \text { to see if the } \\
\text { component already exists }\end{array}$ & - Saves time and cost & $\begin{array}{l}\text { - Google calendar } \\
\text { - WordPress }\end{array}$ \\
\hline Payments & - Offer Payments in the portal & $\begin{array}{l}\text { - Possibility for the citizen to } \\
\text { pay with a credit card or } \\
\text { with internet banking in the } \\
\text { portal }\end{array}$ & $\begin{array}{l}\text { - Official Web portal of } \\
\text { Dubai's police which } \\
\text { allows citizens to pay for } \\
\text { traffic violations }\end{array}$ \\
\hline Workflows & - Workflow enabled systems & $\begin{array}{l}\text { - Possibility for the citizen to } \\
\text { track the status of his } \\
\text { application online }\end{array}$ & $\begin{array}{l}\text { - The portal of e-submission } \\
\text { of annual accounts in the } \\
\text { former Yugoslav Republic } \\
\text { of Macedonia }\end{array}$ \\
\hline Responsiveness & $\begin{array}{l}\text { - Short response time for executing } \\
\text { general services }\end{array}$ & - Efficiency & N/A \\
\hline
\end{tabular}

Table VI. Summary of Web Design Best Practices

\begin{tabular}{|c|c|c|c|}
\hline Subcategory & Details & Advantages & Examples \\
\hline One Stop Shop & $\begin{array}{l}\text { - Single point of entry for all } \\
\text { services }\end{array}$ & $\begin{array}{l}\text { - Preferred model of service delivery } \\
\text { - Citizens don't have to know each } \\
\text { government is responsible for which } \\
\text { service } \\
\text { - Citizens should be able to go to a one } \\
\text { point of access to access all } \\
\text { e-government services } \\
\text { - Easy to use by citizens } \\
\text { - The services of the one stop shops } \\
\text { are heavily used } \\
\text { - Increase customer satisfaction }\end{array}$ & $\begin{array}{l}\text { - In Singapore, the eCitizen } \\
\text { portal that provides more } \\
\text { than } 1600 \text { services is } \\
\text { positioned as a one stop } \\
\text { portal for all government } \\
\text { services } \\
\text { - The Austrian initiative } \\
\text { HELP.gv.at covers } 12 \text { federal } \\
\text { ministries, } 9 \text { federal } \\
\text { provinces, } 80 \text { local } \\
\text { authorities and } 2,359 \\
\text { municipalities }\end{array}$ \\
\hline $\begin{array}{l}\text { Ease of } \\
\text { Navigation }\end{array}$ & $\begin{array}{l}\text { - Ease of navigation and ease } \\
\text { of use } \\
\text { - Intuitive } \\
\text { - User friendly } \\
\text { - Visually pleasing } \\
\text { - Appropriate visual design } \\
\text { - Clear menu structure } \\
\text { - Grouping frequently accessed } \\
\text { services in a list } \\
\text { - FAQs } \\
\text { - Help } \\
\text { - Common look } \\
\text { - Uniform Web pages }\end{array}$ & $\begin{array}{l}\text { - Clear structure help the users know } \\
\text { where exactly (level) they are in the } \\
\text { portal and what other services are } \\
\text { available for them } \\
\text { - Citizens can find pages they are } \\
\text { looking for easily } \\
\text { - Influencing customer satisfaction } \\
\text { and adoption } \\
\text { - Ease of access to services grouped in } \\
\text { a list } \\
\text { - FAQs produce relief to the user } \\
\text { - Common look increases } \\
\text { accessibility and ease of use } \\
\text { - Common look makes it easier for } \\
\text { citizens to access e-government } \\
\text { - Common look reduce some } \\
\text { boundaries to access the portal }\end{array}$ & $\begin{array}{l}\text { - The US portal FirstGov is } \\
\text { user friendly and easy to } \\
\text { navigate (the portal's } \\
\text { services are highlighted in a } \\
\text { list in the home page) } \\
\text { - The eCitizen portal in } \\
\text { Singapore is easy to navigate } \\
\text { and aesthetically pleasing } \\
\text { - The Tunisian national portal } \\
\text { group most used services in } \\
\text { a section in the home page } \\
\text { - Government of Canada is } \\
\text { aiming to provide common } \\
\text { look \& feel to its portals }\end{array}$ \\
\hline Social Networks & $\begin{array}{l}\text { - Use of Web } 2.0 \text { technologies } \\
\text { and platforms } \\
\text { - Social networking, Blogs, } \\
\text { wikis, RSS. }\end{array}$ & $\begin{array}{l}\text { - Strengthens the relationship with the } \\
\text { citizen } \\
\text { - Enables the user to engage with } \\
\text { government } \\
\text { - Help improve the quality of online } \\
\text { public services } \\
\text { - Great adoption of services by citizens } \\
\text { - Better coordination between citizen's } \\
\text { expectation and public services } \\
\text { - Exploit the problem solving skills of } \\
\text { the internet users } \\
\text { - Increase participation } \\
\text { - Improvements in service usage }\end{array}$ & $\begin{array}{l}\text { - Use of social networking } \\
\text { such as Facebook, Twitter, } \\
\text { WordPress, YouTube and } \\
\text { Flickr. }\end{array}$ \\
\hline Personalization & $\begin{array}{l}\text { - Personalization or } \\
\text { customization for citizens } \\
\text { - Targetisation }\end{array}$ & $\begin{array}{l}\text { - Services can be tailored and } \\
\text { customized according to user } \\
\text { profiles and requirements (age, } \\
\text { education level, occupation..) }\end{array}$ & $\begin{array}{l}\text { - In Austria and France, } \\
\text { citizens are able to } \\
\text { customize their driving } \\
\text { licenses and passports }\end{array}$ \\
\hline
\end{tabular}




\begin{tabular}{|c|c|c|c|}
\hline Subcategory & Details & Advantages & Examples \\
\hline & & $\begin{array}{l}\text { - Adapt Web site ergonomics to user } \\
\text { profiles }\end{array}$ & $\begin{array}{l}\text { online. } \\
\text { - 'My messages' area } \\
\text { customized to user profiles } \\
\text { in the My CPF portal in } \\
\text { Singapore } \\
\text { - Korea's national portal offers } \\
\text { the possibility to enter age } \\
\text { and gender to customize the } \\
\text { users' channels and services } \\
\text { of interest }\end{array}$ \\
\hline User Forms & $\begin{array}{l}\text { - Indicate the mandatory fields } \\
\text { - Use drop down menus } \\
\text { - Possibility of a preview } \\
\text { before submitting the form } \\
\text { - Possibility of printing the } \\
\text { accepted form } \\
\text { - Online help when filling the } \\
\text { form } \\
\text { - Information regarding the } \\
\text { stage of completion of the } \\
\text { form }\end{array}$ & $\begin{array}{ll}\text { - } & \text { User friendly } \\
\text { - } & \text { Ease of use }\end{array}$ & $\mathrm{N} / \mathrm{A}$ \\
\hline Industrialization & $\begin{array}{l}\text { - Following industry } \\
\text { guidelines }\end{array}$ & - Increases usability & $\begin{array}{l}\text { - CSS } \\
\text { - ISO/TR } 16982 \text { (ergonomics } \\
\text { of human system interaction } \\
\text { - usability methods } \\
\text { supporting human centered } \\
\text { design) }\end{array}$ \\
\hline Structuration & $\begin{array}{l}\text { - Before starting writing pages } \\
\text { of the portal, one should } \\
\text { spent time writing the } \\
\text { structure of the Web site } \\
\text { - Use of site maps }\end{array}$ & $\begin{array}{l}\text { - Clear structure } \\
\text { - Users stay oriented in the portal }\end{array}$ & $\begin{array}{l}\text { - Most sites in Taiwan have } \\
\text { site maps }\end{array}$ \\
\hline
\end{tabular}

Table VII. Summary of Web Content Best Practices

\begin{tabular}{|c|c|c|c|}
\hline Subcategory & Details & Advantages & Examples \\
\hline Relevancy & $\begin{array}{l}\text { - Content should be citizen } \\
\text { centric, written according to } \\
\text { citizens' needs and designed } \\
\text { with 'its users in mind' } \\
\text { - Grouping information by } \\
\text { theme and target groups }\end{array}$ & $\begin{array}{l}\text { - Helps the citizen find } \\
\text { information easily } \\
\text { - Citizen should not know } \\
\text { for each type of } \\
\text { information which } \\
\text { e-government } \\
\text { organization is } \\
\text { responsible for }\end{array}$ & $\begin{array}{l}\text { - One stop shops } \\
\text { - The Brazilian national portal is } \\
\text { organized by themes and target } \\
\text { groups }\end{array}$ \\
\hline Accessibility & $\begin{array}{l}\text { - Make the site accessible for } \\
\text { everyone, including people } \\
\text { with disabilities. } \\
\text { - Pictures and background } \\
\text { should not be overdone } \\
\text { - Avoid inline multimedia } \\
\text { elements } \\
\text { - Avoid server side image } \\
\text { - Monitor HTML broken links } \\
\text { - Support mobile devices } \\
\text { - Following industry guidelines } \\
\text { in Web content } \\
\text { - Audio CAPTCHAs } \\
\text { - Possibility to hear text of } \\
\text { pages }\end{array}$ & $\begin{array}{l}\text { - Accessibility influence the } \\
\text { success of the portal } \\
\text { - The Web sites become } \\
\text { accessible for people with } \\
\text { disabilities } \\
\text { - Helps reduce the digital } \\
\text { divide among people with } \\
\text { disabilities } \\
\text { - Good download time by } \\
\text { not overdoing pictures } \\
\text { - No accessibility problem } \\
\text { with missing plugins to } \\
\text { access inline multimedia } \\
\text { elements }\end{array}$ & $\begin{array}{l}\text { - Web Content Accessibility guidelines } \\
\text { (WCAG) } \\
\text { - WebXact tool can be used to measure } \\
\text { the compliance with the accessibility } \\
\text { standards } \\
\text { - e-Accessibility checker used by the } \\
\text { UN } \\
\text { - The Austrian HELP.gv.at portal } \\
\text { employs a group of Web experts on } \\
\text { Web design suitable for disabled } \\
\text { people to make information and } \\
\text { services accessible to a wider range } \\
\text { of people including the ones with } \\
\text { disabilities } \\
\text { - Bahraini portal has the possibility } \\
\text { to hear text of pages for people with } \\
\text { vision deficiencies }\end{array}$ \\
\hline Search engines & $\begin{array}{l}\text { - Provides the ability for users } \\
\text { to perform search on }\end{array}$ & $\begin{array}{l}\text { - Search engines make } \\
\text { information and services }\end{array}$ & $\begin{array}{l}\text { - Used as a metric by Brown University } \\
\text { to benchmark e-government portals }\end{array}$ \\
\hline
\end{tabular}




\begin{tabular}{|c|c|c|c|}
\hline Subcategory & Details & Advantages & Examples \\
\hline & information or services & $\begin{array}{l}\text { easier to find and can be } \\
\text { used with metadata to } \\
\text { achieve this } \\
\text { - Metadata helps search } \\
\text { engines find } \\
\text { e-government } \\
\text { information easily }\end{array}$ & \\
\hline Periodical change & $\begin{array}{l}\text { - Having expiry dates or review } \\
\text { dates is important so that the } \\
\text { Web team can update certain } \\
\text { pages automatically }\end{array}$ & $\begin{array}{l}\text { - Users won't be } \\
\text { disappointed with } \\
\text { non-updated information } \\
\text { - Updated information and } \\
\text { current information are } \\
\text { among the dimensions of } \\
\text { Web site quality }\end{array}$ & $\begin{array}{l}\text { - The Austrian portal HELP.gv.at is } \\
\text { empowered by a team of editors } \\
\text { working in parallel with federal } \\
\text { ministries to guarantee that } \\
\text { information is up to date and updated } \\
\text { regularly }\end{array}$ \\
\hline Rich content & $\begin{array}{l}\text { - Rich information ranging } \\
\text { from video clips, publications, } \\
\text { press releases, databases, } \\
\text { Webcasts, interactive maps, } \\
\text { news, laws and regulations } \\
\text { etc... }\end{array}$ & $\begin{array}{l}\text { - Improves citizen } \\
\text { engagement }\end{array}$ & $\begin{array}{l}\text { - Web sites in Singapore are content } \\
\text { rich ( they contain video clips, } \\
\text { publications, press releases and } \\
\text { databases) } \\
\text { - The official portal of Dubai's Police } \\
\text { contains a broad range of } \\
\text { information, news, laws and } \\
\text { regulation } \\
\text { - The Swiss national portal contains } \\
\text { many cartoon videos organized by life } \\
\text { events }\end{array}$ \\
\hline Interactive games & - Interactive games & $\begin{array}{l}\text { - Allowed citizens to learn } \\
\text { in a fun and educational } \\
\text { way } \\
\text { - Increases citizens' } \\
\text { knowledge } \\
\end{array}$ & $\begin{array}{l}\text { - My CPF portal in Singapore included } \\
\text { games about retirement planning } \\
\text { - The e-learning NBPortal in Poland is } \\
\text { also using decision games in } \\
\text { economics }\end{array}$ \\
\hline $\begin{array}{l}\text { Mobile } \\
\text { Applications }\end{array}$ & $\begin{array}{l}\text { - Downloadable mobile } \\
\text { applications }\end{array}$ & - Increases service mobility & $\begin{array}{l}\text { - The Korean portal offers mobile } \\
\text { applications }\end{array}$ \\
\hline Statements & $\begin{array}{l}\text { - Disclaimers, copyrights and } \\
\text { privacy and security } \\
\text { statements } \\
\text { - Government should be } \\
\text { transparent with the flow of } \\
\text { information } \\
\end{array}$ & $\begin{array}{l}\text { - Detailed information } \\
\text { concerning security, } \\
\text { privacy and data } \\
\text { protection could enhance } \\
\text { the trust of the citizen }\end{array}$ & $\begin{array}{l}\text { - Web sites in Singapore have privacy } \\
\text { statements } \\
\text { - In US Web sites feature privacy and } \\
\text { security statements }\end{array}$ \\
\hline Translations & $\begin{array}{l}\text { - Having an English version and } \\
\text { translations of the portal }\end{array}$ & $\begin{array}{l}\text { - Helps foreign people } \\
\text { access the portal }\end{array}$ & $\begin{array}{l}\text { - All sites in Taiwan have a fully } \\
\text { featured English version } \\
\text { - Sites in the US can be translated } \\
\text { into over } 30 \text { languages }\end{array}$ \\
\hline Understandability & $\begin{array}{l}\text { - Links and texts used in the } \\
\text { portal must be easily } \\
\text { comprehended } \\
\text { - The information of the Web } \\
\text { site should be clear and } \\
\text { understandable } \\
\text { - Content should be written in } \\
\text { plain language }\end{array}$ & $\begin{array}{l}\text { - Guarantee equal } \\
\text { e-government } \\
\text { opportunity } \\
\text { - Audience can understand } \\
\text { first time they hear or } \\
\text { read }\end{array}$ & - US plain language initiative \\
\hline
\end{tabular}

Table VIII. Summary of External Best Practices

\begin{tabular}{|l|l|l|l|}
\hline Subcategory & Details & Advantages & Examples \\
\hline E-Participation & - Seeking feedback from the & - Contribute in the policy & - Surveys and polls to identify citizens' \\
& users & making process & need \\
& - Possibility to rate services & - Feedback can be user to & - Computerized surveys \\
& - Web site assessments & launch newer versions of & - Online forums \\
& - Surveys for users and & the portal & - Chat room \\
& non-users & - Improves public services & - Comment forms \\
& - Possibility to ask an expert & and interaction with the & - Suggestion programs \\
& - Tracing hard data & citizen & - e-Petitions \\
& (frequently accessed & - Encourage and promote & \\
\hline
\end{tabular}




\begin{tabular}{|c|c|c|c|}
\hline Subcategory & Details & Advantages & Examples \\
\hline & $\begin{array}{l}\text { products, the length of time } \\
\text { spent on each page ) }\end{array}$ & $\begin{array}{l}\text { e-participation } \\
\text { - Increase satisfaction } \\
\text { - Provide help and answers } \\
\text { to users } \\
\text { - Tracking data can be used } \\
\text { to enhance the Web site }\end{array}$ & \\
\hline Advertising & $\begin{array}{l}\text { - Ads and advertisements } \\
\text { - Promote and increase } \\
\text { awareness of public services }\end{array}$ & $\begin{array}{l}\text { - Help citizens to be aware } \\
\text { of the services and } \\
\text { information available to } \\
\text { them }\end{array}$ & $\begin{array}{l}\text { - Canada advertises its Web sites in printed } \\
\text { brochures, TV and Radio } \\
\text { - The Belgian government is using digital } \\
\text { television for job advertisement }\end{array}$ \\
\hline Referencing & - Search Engine Optimization & $\begin{array}{l}\text { - Help citizens find services } \\
\text { and information }\end{array}$ & $\begin{array}{l}\text { - The Web site } \\
\text { "http://marketing.grader.com/" can be } \\
\text { used to grade and enhance SEO practices. }\end{array}$ \\
\hline Incentives & $\begin{array}{l}\text { - Offering incentives to users } \\
\text { to promote the Web channel }\end{array}$ & $\begin{array}{l}\text { - Promote and increase } \\
\text { service usage }\end{array}$ & $\begin{array}{l}\text { - France, Ireland and Singapore offer an } \\
\text { extended period for filling taxes } \\
\text { - In the United States, online users profit } \\
\text { from filling their taxes for free }\end{array}$ \\
\hline Contests & $\begin{array}{l}\text { - Making public data available } \\
\text { for public } \\
\text { - Organizing contests }\end{array}$ & $\begin{array}{l}\text { - Encourage participation } \\
\text { and collaboration } \\
\text { - Create innovative services } \\
\text { in order to help solve } \\
\text { problems expressed by } \\
\text { citizens } \\
\text { - Citizens become } \\
\text { producers }\end{array}$ & $\begin{array}{l}\text { - The district of Columbia in Washington } \\
\text { Apps contest }\end{array}$ \\
\hline
\end{tabular}

\section{References}

[1] Allah, A. F., Cheikhi, L., Qutaish, R. A., \& Idri, A. (2014). E-government portals best practices: A comprehensive survey. Electronic Government, An International Journal, 11(1-2), 101-132.

[2] Halachmi, A. (2004). E-government theory and practice: The evidence from Tennessee (USA). Front. Public Adm.

[3] Assar, S. (2011). Practical Studies in E-Government.

[4] Forfás, eGovernment: International Best Practices. 2008.

[5] World Bank, Designing and Implementing E-Government: Key Issues, Best Practices and Lessons Learned.

[6] Berntzen, L., \& Olsen, M. G. (2009). Benchmarking e-government-a comparative review of three international benchmarking studies. Proceedings of the Third International Conference on Digital Society, (pp. 77-82).

[7] Allah, A. F., Cheikhi, L., Qutaish, R. A., \& Idri, A. (2014). E-government maturity models: A comparative study. International Journal of Software Engineering and Applications, 5(3), 71-91.

[8] Layne, K., \& Lee, J. (2001). Developing fully functional e-government: A four stage model. Gov. Inf. Q., 18(2), 122-136.

[9] United Nations Department of Economic and Social Affairs. UN E-Government Survey 2012: E-Government for the People, United Nations. New York, United States, 2012.

[10] Andersen, K. V., \& Henriksen, H. Z. (2006). E-government maturity models: Extension of the Layne and Lee model. Gov. Inf. Q., 23(2), 236-248.

[11] Alhomod, S. M., Shafi, M. M., Kousarrizi, M. N., Seiti, F., Teshnehlab, M., Susanto, H., Almunawar, M. N., Tuan, Y. C., Aksoy, M. S., \& Batawi, Y. A. (2012). Best practices in E government: A review of some 
Innovative models proposed in different countries. International Journal Electr. Computer. Science, 12(1), 1-6.

[12] Hiller, J. S., \& Belanger, F. (2001). Privacy strategies for electronic government. E-Gov., 162-198.

[13] Almazan, R. S., \& Garcia, J. R. G. (2008). E-government portals in Mexico.

[14] Cisco IBSG, E-Government Best Practices Learning from Success, Avoiding the Pitfalls.

[15] Karokola, G., \& Yngström, L. (2009). Discussing e-government maturity models for developing world-security view. Proceedings of the Conference on Information Security South Africa (pp. 81-98).

[16] West, D. M. (2004). E-government and the transformation of service delivery and citizen attitudes. Public Adm. Rev., 64(1), 15-27.

[17] Moon, M. J. (2002). The evolution of e-government among municipalities: Rhetoric or reality?. Public Adm. Rev., 62(4), 424-433.

[18] Toasaki, Y. (2003). E-government from A user's perspective. APEC Telecommunication and Information Working Group.

[19] Deloitte Consulting and Deloitte \& Touche, Deloitte \& Touche. (2000). At the dawn of e-government: The citizen as customer. N. Y. Deloitte Res.

[20] Howard, M. (2001). E-government across the globe: How will'e'change government. E-Gov.

[21] Shahkooh, K. A., Saghafi, F., \& Abdollahi, A. (2008). A proposed model for e-government maturity. Information and Communication Technologies: From Theory to Applications.

[22] Lee, G., \& Kwak, Y. H. (2012). An open government maturity model for social media-based public engagement. Gov. Inf. $Q$.

[23] Siau, K., \& Long, Y. (2005). Synthesizing e-government stage models-a meta-synthesis based on meta-ethnography approach. Ind. Manag. Data Syst., 105(4), 443-458.

[24] Wescott, C. G. (2001). E-government in the Asia-pacific region. Asian Journal Polit. Sci., 9(2), 1-24.

[25] Chandler, S., \& Emanuels, S. (2002), Transformation not automation. Proceedings of 2nd European Conference on E-government (pp. 91-102).

[26] Kim, D. Y., \& Grant, G. (2010). E-government maturity model using the capability maturity model integration. Journal Syst. Information Technol., 12(3), 230-244.

[27] Chen, J., Yan, Y., \& Mingins, C. (2011). A three-dimensional model for e-government development with cases in China's regional e-government practice and experience. Proceedings of the 2011 Fifth International Conference on Management of e-Commerce and e-Government (pp. 113-120).

[28] Windley, P. J. (2002). eGovernment maturity. USA Wind. Technolometria.

[29] Reddick, C. G. (2004). A two-stage model of e-government growth: Theories and empirical evidence for US cities. Gov. Inf. Q., 21(1), 51-64.

[30] Rohleder, S. J., \& Jupp, V. (2002). E-government leadership: Engaging the customer. Accenture.

[31] Government on the Web II.

[32] Netchaeva, I. (2002). E-government and e-democracy a comparison of opportunities in the north and south. Int. Commun. Gaz., 64(5), 467-477.

[33] Baum, C., \& Maio, A. D. (2000). Gartner's four phases of e-government model. Gart. Group.

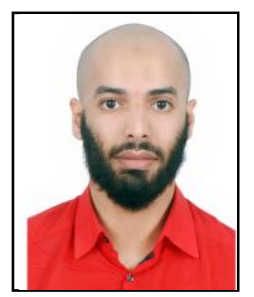

Abdoullah Fath-Allah holds a bachelor degree in computer science in 2005 and a master degree in computer networks with a minor in software engineering from Alakhawayn University in Ifrane, Morocco (AUI), in 2007. Abdoullah has more than 8 years' experience in industry, and he is an e-HR portals' consultant. He is currently a PhD student at ENSIAS (Morocco). 
Laila Cheikhi is a professor at Computer Science and Systems Analysis School (ENSIAS, Rabat, Morocco). She received a M.Sc. from University of Montréal in 2004 and Ph.D. from ETS, University of Quebec at Montreal, and both in software engineering, in 2008. She has over eight years of experience in computer engineering at the Ministry of Finance of Morocco. Her research interests include software quality models, software metrics, software engineering ISO standards, software product and process quality, software engineering principles and data analysis.

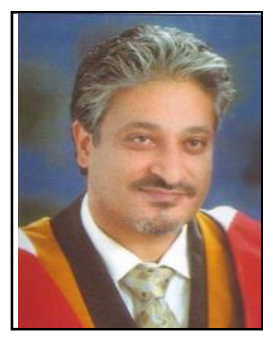

Rafa E. Al-Qutaish is an associate professor at École de Technologie Supérieure (ÉTS), University of Québec, Canada. He received B.Sc. in computer science and M.Sc. in software engineering degrees in 1993 and 1998, respectively. Also, he received the Ph.D. degree in software engineering from the School of Higher Technology (ÉTS), University of Québec, Canada in 2007. His research interests are in software measurement, software product quality, software engineering standardization, reverse engineering, software comprehension and maintenance, and compiler construction. Dr. Al-Qutaish is a senior member of the IEEE \& IEEE-CS, and also a senior member of the IACSIT.

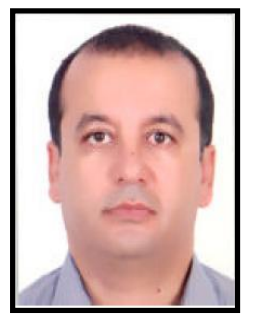

Ali Idri is a professor at Computer Science and Systems Analysis School (ENSIAS, Rabat, Morocco). He received DEA Master in 1994 and a doctorate of 3rd Cycle degrees in computer science, both from the University Mohamed V of Rabat in1997. He has received his Ph.D. in cognitive computer sciences from ETS, University of Quebec at Montreal in 2003. His research interests include software cost estimation, software metrics, fuzzy logic, neural networks, genetic algorithms and information sciences. 